\title{
Strategi Guru PAI Dalam Menghadapi Kesulitan Membaca Alquran Peserta Didik Kelas V SD Negeri 04 Kampung Dalam
}

Annisya Mulia', Ahmad Kosasih ${ }^{2}$, Mhd Zen ${ }^{3}$

annisyamulia66@gmail.com¹, ahmadkosasihtanjung@gmail.com², mhdzenpai@gmail.com³ Universitas Negeri Padang1,2,3

\begin{tabular}{|c|c|}
\hline ARTICLE INFO & \multirow{11}{*}{$\begin{array}{l}\text { Penelitian ini bertujuan untuk mengetahui } \\
\text { penyebab kesulitan yang dihadapi peserta didik dalam } \\
\text { membaca Alquran di SD Negeri } 04 \text { Kampung Dalam. } \\
\text { Jenis penelitian yang digunakan adalah penelitian } \\
\text { lapangan dan metode yang digunakan adalah metode } \\
\text { kualitatif dengan pendekatan deskriptif. Hasil } \\
\text { penelitian ini menjelaskan bahwa penyebab kesulitan } \\
\text { yang di hadapi peserta didik adalah terbata-bata dalam } \\
\text { membaca Alquran, belum mengetahui tanda baca, } \\
\text { kurang menguasai kaidah ilmu tajwid, tidak mengenal } \\
\text { huruf hijaiyah, lupa, malas dalam belajar serta tidak } \\
\text { percaya diri dan takut salah dalam membaca Alquran. } \\
\text { Sedangkan faktor penyebab kesulitan membaca } \\
\text { Alquran terbagi menjadi } 2 \text { yaitu internal dan eksternal. } \\
\text { Faktor internal seperti kurangnya motivasi dalam diri } \\
\text { peserta didik dan malas dalam belajar, faktor } \\
\text { eksternalnya yaitu lingkungan keluarga yang kurang } \\
\text { mendukung, lingkungan teman sepermainan yang } \\
\text { kurang memadai serta waktu yang sangat terbatas. } \\
\text { Faktor pendukungnya adalah sarana prasarana yang } \\
\text { memadai seperti buku dan Alquran. }\end{array}$} \\
\hline Article history: & \\
\hline Received 5 Agustus 2021 & \\
\hline Revised 24 Agustus 2021 & \\
\hline $\begin{array}{l}\text { Accepted } \\
2021\end{array}$ & \\
\hline Key & \\
\hline Strategi, Kesulitan, & \\
\hline Clonflic & \\
\hline None & \\
\hline Funding: & \\
\hline$N$ & \\
\hline
\end{tabular}

Corresponding Author: Annisya Mulia, Department Islamic Education, Faculty of Social Science Universitas Negeri Padang, Indonesia, Email: annisyamulia66@gmail.com Phone No.: +62813-727-68487

(c) (7) Copyright@2021, Author(s)

\section{Pendahuluan}

Alquran ialah kalam Allah yang diturunkan kepada Nabi Muhammad diriwayatkan secara mutawatir, membacanya terhitung sebagai ibadah dan tidak ditolak kebenarannya. (Al-hafidz, 2009 : 55). Al- Qur'an merupakan pedoman bagi umat Islam pada setiap aspek kehidupan manusia. (Tarwiyah, 2008). Bacaan Alquran dalam Islam dituntut dengan bacaan yang sempurna. (Mernawati, 2011: 14). Sebagaimana yang diterangkan dalam QS. Al-Muzammil ayat 4, berbunyi: 

lahan."

Artinya: "Atau lebih dari seperdua itu dan bacalah Alquran itu dengan perlahan-

Berdasarkan ayat tersebut Allah telah memerintahkan agar membaca Alquran dengan tartil (perlahan-lahan). Demikian pula terdapat hadist yang memerintahkan tentang membaca Alquran sebagaimana yang diriwayatkan oleh An-Nu'man ibn Basyir artinya:

Rasulullah SAW bersabda: "sebaik-baik ibadah umatku ialah membaca Alquran. (HR. Al-Baihaqi)"

Disamping itu juga terdapat dalam Q.S Al-Baqarah ayat 121

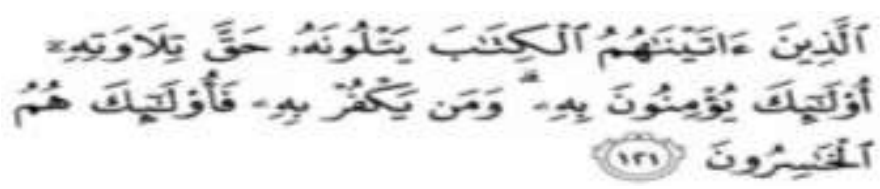

"Orang-orang yang telah kami beri al-Kitab kepadanya, mereka membacanya dengan bacaan yang sebenarnya, mereka itu beriman kepadanya. Dan barangsiapa yang ingkar kepadanya, maka mereka itulah orang-orang yang rugi."

Dari ayat dan hadist tersebut dapat dipahami bahwa Alquran sangat penting untuk dipelajari dengan baik dan sesuai dengan kaidah tajwid yang benar. Keutamaan membaca Alquran dalam kitabnya Syekhul Islam Muhyiddin Abu Zakariyya Yahya bin Syaraf An-Nawawi di antaranya: Alquran akan menjadi syafaat atau penolong di hari kiamat untuk para pembacanya, orang yang mempelajari dan mengajarkan Alquran merupakan sebaik-baik manusia, untuk orang-orang yang mahir membaca Alquran maka kelak ia akan bersama para malaikat-Nya, untuk mereka yang belum lancar dalam membaca dan mengkhatamkan Alquran, tidak boleh bersedih, sebab Allah tetap berikan dua pahala, Alquran dapat meningkatkan derajat kita di mata Allah (Marki, 2021).

Mengingat keutamaan Alquran sangat banyak faedahnya, dan juga Alquran pedoman hidup bagi umat manusia, diperlukan perhatian khusus kepada anak-anak yang sulit dalam membaca Alquran, salah satunya melalui mata pelajaran di Sekolah Dasar yaitu pendidikan agama Islam yang berlandaskan Alquran dan sunnah.

Observasi yang penulis lakukan di SD Negeri 04 Kampung Dalam pada tanggal 26 Desember 2020 masih banyak siswa yang mengalami kesulitan membaca Alquran, adapun kesulitan yang dialami membaca Alquran ialah pengucapan makharijul huruf (tempat keluarnya huruf atau letak pengucapan huruf Qur'an) ditemukannya 9 siswa

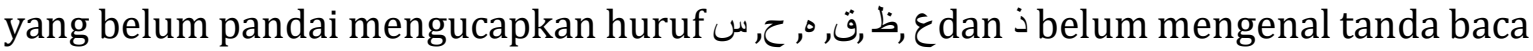
seperti tanda wakaf dalam Alquran yang sebenarnya berhenti tapi ada sebagian anak membaca terus saja, pemahaman ilmu tajwid yang masih kurang sehingga membuat anak-anak tidak begitu paham akan kaidah tajwib yang baik dan benar, serta kelancaran bacaan Alquran yang masih terbata-bata. Misalnya seperti membaca huruf hijaiyah masih ada siswa yang tidak tahu cara membacanya dan tidak lancar dalam membacanya. Dari observasi tersebut maka penulis memperoleh hasil test bahwa ada 4 siswa yang pandai membaca Alquran, dan ada 9 orang yang tidak bisa membaca Alquran dengan kaidah tajwid yang benar. 
Annisya Mulia dan Ahmad Kosasih: Strategi Guru PAI dalam Menghadapi Kesulitan Membaca...

Maka dalam permasalahan ini penulis mengangkat judul tentang strategi guru PAI dalam mengatasi kesulitan membaca Alquran bagi siswa kelas V di SD Negeri 04 Kampung Dalam. Penulis akan menjelaskan mengenai “Strategi Guru Pendidikan Agama Islam Dalam Mengatasi Kesulitan Membaca Alquran Di SD Negeri 04 Kampung Dalam ".

\section{Tinjauan Pustaka}

\section{Strategi Pembelajaran}

Jenis-jenis Strategi Pembelajaran Alquran

Strategi pembelajaran Alquran menurut Zarkarsyi adalah sebagi berikut (Zarkarsyi, 1987):

1) Sistem sorogan atau Individu (privat)

Dalam prakteknya santri atau siswa bergiliran satu persatu menurut kemampuan membacanya, (mungkin satu, dua, atau tiga bahkan empat halaman), kemudian diperiksa bacaan yang kurang fasih dalam membacanya sekaligus bisa dijelaskan.

Pembelajaran pada strategi ini pada dasarnya bisa di implementasikan dengan menggunakan strategi inquiri yaitu dengan memberikan pertanyaan kepada siswa tentang apa yang sudah dibacanya sudah dibacanya betulkah bacaan yang sudah dibacanya atau hanya asal-asalan saat membacanya. Selain itu guru juga bisa langsung menjelaskan secara verbal tentang apa yang di baca dibaca siswa pada suatu waktu tertentu atau yang disebut dengan system strategi ekspositori.

2) Klasikal Individu

Dalam prakteknya sebagian waktu guru dipergunakan untuk menerangkan pokok-pokok pelajaran, sekedar dua atau tiga halaman dan seterusnya, sedangkan membacanya sangat ditekankan, kemudian dinilai prestasinya.

Dalam strategi pembelajaran Alquran ini termuat strategi pembelajaran yang hampir sama dengan strategi sorogan hanya saja pada strategi ini membutuhkan waktu yang cukup lama ekspository maupun inquiri. Strategi ekspositori yaitu pada saat guru menjelaskan pokok-pokok pelajaran dengan menggunakan ceramah dan inquiri saat guru menjelaskan dengan sistem tanya jawab.

3) Klasikal Baca Simak

Dalam praktiknya guru menerapakan pokok pelajaran yang rendah (klasikal), kemudian para siswa pada pelajaran ini dites satu persatu atau disimak oleh semua siswa.Demikian seterusnya sampai pada pokok pelajaran berikutnya.Pada praktek nya strategi semacam ini guruhanya bisa menggunakan strategi pembelajaran ekspositori karena guru hanya menerangkan pokok pembelajaran yang rendah.

Sedangkan Reigeluth dkk (dalam Muhaimin dkk) mengklasifikasikan tiga variabel dalam pembelajaran, yaitu;

1) Kondisi pembelajaran yang didefinisikan sebagai faktor yang mempengaruhi efek metode dalam meningkatkan hasil pembelajaran adalah interaksi dengan metode pembelajaran, dan hakikatnya tidak dapat dimanipulasi.

2) Metode pembelajaran yang didefinisikan sebagai cara-cara yang berbeda untuk mencapai hasil pembelajaran yang berbeda, pada dasarnya semua cara itu dapat dimanipulasi oleh perancang pembelajaran atau pengajar. 
Variabel pembelajaran ini diklasifikasikan lagi menjadi tiga jenis, yaitu: Strategi pengorganisasian, Strategi penyampaian isi pembelajaran, dan strategi pengelolahan pembelajaran.

3) Hasil pembelajaran yang didefinisikan mencakup semua efek yang dapat dijadikan sebagai indikator tentang nilai dari penggunaan metode pembelajaran di bawah kondisi pembelajaran yang berbeda adalah bisa hasil berupa hasil nyata (actual outcomes), dan hasil yang diinginkan (diserid outcomes). Actual outcomes adalah hasil yang nyata dari penggunaan suatu metode di bawah kondisi tertentu, sedangkan desired outcomes adalah tujuan yang ingin dicapai, yang sering mempengaruhi keputusan perancang pembelajaran atau pengajar dalam melakukan pilihan metode yang sebaiknya digunakan (Muhaimin, 1996).

Dalam pengimplementasian strategi ada ada empat tingkatan tempo atau istilah metode pembelajaran Al Qur'an yang telah disepakati oleh ahli Tajwid, yaitu (Wahyudi, 2007):

1) At-Tartil yaitu Membaca dengan pelan dan tenang, mengeluarkan setiap huruf dari makhrajnya dengan memberikan sifat-sifat yang dimilikinya, baik asli maupun baru datang (hukum-hukumnya) serta memperhatikan makna (ayat).

2) Al-Hadr yaitu membaca dengan cepat tetapi masih menjaga hukumhukumnya.

3) At-Tadwir yaitu bacaan sedang tidak terlalu cepat juga tidak terlalu pelan, tetapi pertengahan antara keduanya.

At-Tahqiq yaitu membaca seperti halnya tartil tetapi lebih tenang dan perlahan-lahan. Tempo ini hanya boleh dipakai untuk belajar (latihan) dan mengajar. Dan tidak boleh dipakai pada waktu sholat atau menjadi imam.

\section{Kesulitan Membaca Alquran}

Bentuk-bentuk kesulitan membaca Alquran seperti dalam membaca Alquran, yakni susah untuk melafalkan huruf Alquran dengan bahasa lisan yang terstruktur dari kata dan kalimat Arab.

Ilmu tajwid adalah pengetahuan mengenai kaidah-kaidah membaca Alquran dengan baik dan benar. Yang dimaksud dengan baik dan benar adalah ketepatan melafalkan huruf-huruf hijaiyah sesuai dengan kaidah tajwid yang benar, seperti ada yang didengungkan, disamarkan, dipendekkan, dipanjangkan dan lain sebagainya. Tujuan ilmu tajwid adalah memperbaiki cara membaca Alquran (Chaer. 2013: 55).

Berdasarkan hal tersebut dapat disimpulkan bahwasannya bentuk kesulitan dalam membaca Alquran dapat berupa pengucapan lafadz, panjang pendek, pengucapan huruf hijaiyah maupun mempraktekkan hukum bacaan tajwid.

Hal tersebut dapat dilakukan dengan cara mempelajari dan mengaktualisasikan kaidah ilmu tajwid saat membaca Alquran, dan juga disarankan sering mendengat murotal syekh-syekh agar pengucapannya lebih bagus lagi dan tentunya perlu didampingi oleh tutor / guru. Ada beberapa kategori kesulitan dalam membaca Alquran:

1. Kesulitan dalam mengucapkan huruf hijaiyah, ada sebagian siswa yang sulit membedakan huruf hijaiyah. Seperti halnya:

a) huruf $ث$ dengan

b) huruf $\tau$ dengan $。$ 
Annisya Mulia dan Ahmad Kosasih: Strategi Guru PAI dalam Menghadapi Kesulitan Membaca...

c) huruf dengan

d) huruf bengan ذ

e) huruf I dengan $\varepsilon$

2. Kesulitan dalam membaca huruf yang bertajwid.

Dalam membaca qur'an di perlukan membaca sesuai dengan kaidah tajwid yang benar, seperti ditemukan halnya dalam pembacaan huruf hijaiyah ب yang mana ba' disini dibaca panjang 2 harakat. Dan juga pernah ditemukan anak membacanya dengan panjang 5 harakat hal tersebut justru salah dalam pembacaan kaidah tajwid yang benar.

Kesulitan dalam membaca huruf yang bersambung. Hal ini ditemukan sulitnya siswa dalam membaca huruf yang bersambung. Ada yang ditemukan ketika membaca huruf yang bersambung tersebut siswa rentan akan tajwid yang tidak sesuai dengan kaidah yang semestinya.

Faktor Penyebab Kesulitan Membaca Alquran

Faktor internal

1) Daya ingat rendah. Daya ingat rendah sangat memengaruhi hasil belajar seseorang. Anak yang sudah belajar dengan keras namun daya ingat di bawah rata-rata hasilnya akan kalah dengan anak yang mempunyai daya ingat tinggi.

2) Terganggunnya alat-alat indra. Kita semua pasti tahu, kesehatan merupakan salah satu hal penting yang menentukan aktivitas sehari-hari.Begitu juga dalam belajar. Seseorang yang mengalami cacat mat tentu akan merasa kesulitan saat mempelajari hal-hal yang berhubungan dengan dunia penglihatan. Ataupun yang menderita tunarunggu, tentu ia akan kesulitan saat mempelajari pelajaran seni musik dan sebagainnya.

3) Usia anak. Usia juga merupakan salah satu faktor yang dapat menyebabkan gangguan belajar pada anak. Usia yang terlalu mudaUsia anak. Usia juga merupakan salah satu faktor yang dapat menyebabkan gangguan belajar pada anak. Usia yang terlalu muda ataupun usia yang sudah terlalu tua dapat menyebabkan individu kesulitan untuk menerima materi belajar.

4) Jenis kelamin. Jenis kelamin juga mempengaruhi hasil belajar anak. Anak perempuan biasannya lebih mudah belajar yang berhubungan dengan ilmu sosial dibanding ilmu pasti. Sedangkan, anak laki-laki lebih menyukai pelajaran yang langsung berhubungan dengan praktik.

5) Kebiasaan belajar atau rutinitas. Seorang anak yang terbiasa belajar dengan kata lain ada jadwal tertentu setiap harinya juga akan mengalami perbedaan prestasi dengan anak yang belajar tidak tertentu setiap harinya.

6) Tingkat kecerdasan (Intelegensi). Meskipun bukan satu-satunya sebagai yang menentukan kecerdasan seseorang, intelegensi juga memberi pengaruh pada kesulitan belajar membaca seseorang.

7) Minat. Minat timbul dalam diri seseorang untuk memerhatikan, menerima, dan melakukan sesuatu tanpa ada yang menyuruh dan sesuatu itu dinilai penting dan berguna bagi dirinya. Minat belajar yang tinggi dapat menuntun anak untuk belajar lebih baik lagi. 
8) Emosi (perasaan). Emosi juga mempengaruhi hasil belajar seseorang. Emosi diartikan sebagai tergugahnya perasaan yang disertai dengan perubahanperubahan dalam tubuh. Emosi itulah yang akan membantu mempercepat proses pembelajaran.

9) Motivasi atau cita-cita. Motivasi memegang peranan penting dalam pencapaian keberhasilan sesuatu hal. Motivasi erat sekali hubungannya dengan tujuan yang akan dicapai. Motivasi yang tinggi tercermin dari ketekunan yang tidak mudah patah untuk mencapai kesuksesan walaupun berbagai kesulitan menghadang.

10) Sikap dan perilaku. Dalam kondisi dan perilaku yang terganggu tentunya anak tidak dapat tumbuh dan berkembang secara optimal.

11) Konsentrasi. Anak dengan konsentrasi tinggi untuk belajar akan tetap belajar meskipun banyak faktor memengaruhinya.

12) Rasa percaya diri. Seseorang yang merasa dirinya mampu mempelajari sesuatu maka keyakinanya itu yang akan menuntunnya menuju keberhasilan.

13) Kematangan atau kesiapan. Dalam belajar, kematangan atau kesiapan itu sangat menetukan. Oleh karena itu, setiap usaha belajar akan lebih berhasil bila dilakukan bersamaan dengan tingkat kematangan seseorang (subini: 19-25).

Faktor eksternal

1) Faktor keluarga. Keluarga merupakan pusat pendidikan yang utama dan pertama. Tetapi dapat juga sebagai faktor penyebab kesulitan belajar.

2) Suasana rumah. Suasana keluarga yang sangat ramai atau gaduh, tidak mungkin anak dapat belajar dengan baik. Hendaknya suasana di rumah selalu dibuat menyenangkan, tentram, dan damai. Keadaan ini akan menguntungkan bagi kemajuan belajar anak.

3) Keadaan ekonomi. Ekonomi keluarga yang kurang mampu terkadang membuat anak lebih rajin dalam bekerja membantu orang tua mereka dari pada belajar. Dan untuk anak yang terlahir dalam keluarga ekonomi yang belebihan akan membuat mereka malas untuk belajar dan lebih memiih untuk bersenangsenang.

4) Faktor sekolah. Yang dimaksud sekolah adalah semua komponen yang ada dalam sekolah maupun yang terjadi saat proses pembelajaran di kelas maupun du luar kelas. Semisal metode mengajr guru yang tidak sesuai dengan peserta didik ataupun sarana dan prasarana yang ada di sekolah.

5) Lingkungan sosial. Lingkungan sosial di sini adalah lingkungan tempat tinggal, aktivitas dalam masyarakat, dan juga teman sepergaulan.Diantara ketiga lingkungan sosial ini yang paling berpengaruh pada diri peserta didik adalah lingkungan teman sepergaulan. Karena teman bergaul mempunyai kesempatan yang lebih besar dan cepat masuk untuk memengaruhi temannya (Ahmad, 2008).

\section{Metode Penelitian}

Penelitian ini memakai metode kualitatif melalui jenis penelitian field research, yaitu mencari data yang ada dilapangan yang berhubungan dengan masalah yang akan dibahas. Penelitian lapangan (field research), terjun kelapangan, terlibat dengan guru dan peserta didik untuk mendapatkan gambaran yang lebih komprehensif tentang 
Annisya Mulia dan Ahmad Kosasih: Strategi Guru PAI dalam Menghadapi Kesulitan Membaca...

situasi setempat. Menggunakan metode deskriptif analisis yaitu menggambarkan keadaan, aktual dan akurat untuk memperoleh data yang lengkap. Metode pengumpulan datanya berupa wawancara dan dokumentasi (Lexy. J. Moleong, 2009). Teknik pengumpulan data: observasi, wawancara, dokumentasi. Teknik analisa data: analisis data, reduksi data, penyajian data, verifikasi data. Analisis data itu dilakukan sejak awal penelitian hingga pada akhir penelitian (pengumpulan data). Analisis data pada penelitian kualitatif dilakukan melalui pengaturan data secara logis dan sistematis (Al-Manshu. 2014: 234).

\section{Hasil dan Pembahasan}

Bentuk-bentuk kesulitan membaca Alquran

Banyak penyebab dari kesulitan membaca Alquran seperti tidak mengetahui dan mengenal huruf hijaiyah, tidak mengenal kaidah ilmu tajwid, lupa, malas, tidak ada, panjang pendek dalam membaca Alquran, terbata-bata dan ragu-ragu dalam membaca Alquran, tidak percaya diri dalam membaca Alquran karena takut salah serta lambat dalam menangkap pelajaran, terbatasnya alat digital yang dimiliki peserta didiik, dan waktu yang tidak kondusif. Dengan berbagai kesulitan tersebut guru dapat mengetahui apa tindakan selanjutnya yang akan dilakukan agar peserta didik bisa membacaAlquran sesuai dengan kaidah tajwid. Untuk itu guru perlu lebih memperhatikan peserta didik demi perkembangan peserta didik kedepannya.

Berdasarkan hasil wawancara yang dilakukan kepada 13 orang informan, hasil analisis secara nyata mendapati bahwa terdapat enam tema penting terkait apa sesungguhnya kesulitan peserta didik dalam membaca Alquran. Enam tema tersebut dapat terlihat pada gambar 1, berikut.

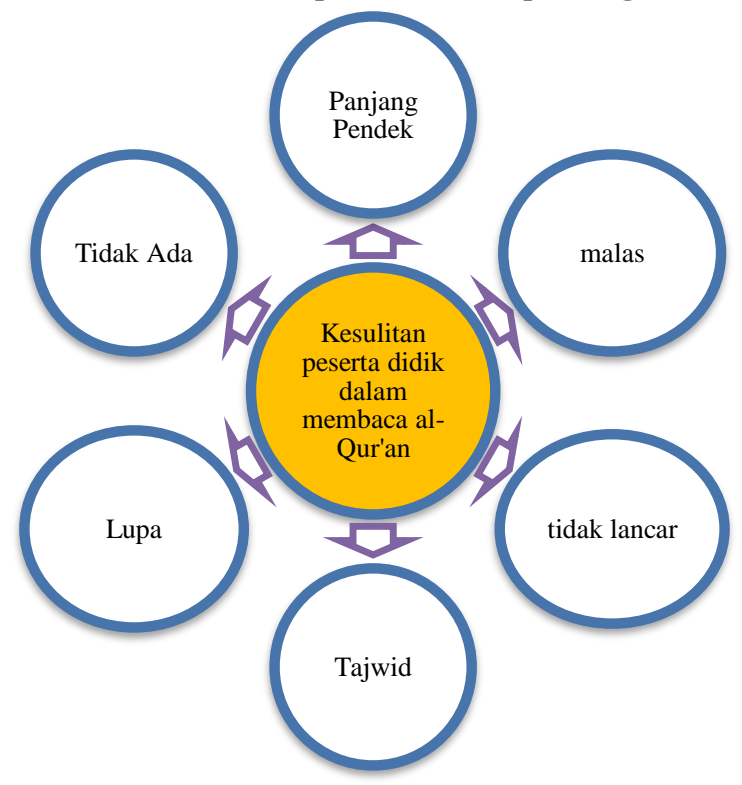

Gambar 1. Deskripsi Kesulitan Peserta Didik Dalam Membaca Alquran

Berdasarkan gambar 1, dapat penulis jelaskan bahwa setelah diadakan wawancara mendalam dengan informan maka terdapat 6 kesulitan peserta didik, enam tema tersebut adalah i) panjang pendek, ii) malas, iii) tidak lancar, iv) tajwid, v) lupa vi) tidak ada 
Penjelasan dan gambar diatas didasarkan atas informasi yang peneliti ambil dilapangan melalui obseravsi dan wawancara yang peneliti terjun langsung ke lapangan untuk menjaga validitas data yang dibutuhkan.

Sebab-sebab kesulitan membaca Alquran

Sebab-sebab kesulitan Membaca Alquran yang ditemukan di SD Negeri 04 Kampung Dalam adalah :

a. Kurangnya motivasi dari peserta didik itu sendiri.

b. Ada beberapa peserta didik tidak mengikuti kegiatan belajar tambahan seperti belajar di TPA tempat tinggal masing-masing.

c. Kurangnya dukungan dari lingkungan dan teman sebaya.

d. Lingkungan yang kurang kondusif akibat dari dampak covid 19 yang mengakibat waktu pelajaran menjadi sangat singkat yaitu 2 jam perharinya.

Faktor penyebab kesulitan membaca Alquran di kelas V SD Negeri 04 Kampung Dalam

Faktor penyebab kesulitan membaca Alquran sehingga rendahnya hasil belajar peserta didik, guru lebih berperan aktif agar peserta didik lebih meningkatkan pemahaman membaca Alquran. Faktor penyebab terbagi atas 2, pertama faktor pendukung dan yang kedua faktor penghambat. Untuk faktor pendukung pembelajaran seperti, sarana prasarana yang cukup memadai, partisipasi dari guru untuk meningkatkan membaca Alquran. Selanjutnya faktor penghambat, faktor penghambat terbagi atas 2, pertama faktor internal yakni faktor dari dalam diri peserta didik, kurangnya motivasi dan adanya rasa malas dari peserta didik sehingga rendahnya hasil belajar pada peserta didik. Yang kedua faktor eksternal yakni dari lingkungan keluarga, kurangnya dukungan dari keluarga sehingga menyebabkan peserta didik tidak bisa membaca Alquran serta faktor dari lingkungan sepermainan, yang menyebabkan peserta didik lalai dan terpengaruh, sehingga lupa dan ketidakmauan dalam membaca Alquran.

Strategi Guru Pendidikan Agama Islam dalam mengatasi kesulitan membaca Alquran di kelas V SD Negeri 04 Kampung Dalam.

Strategi guru PAI dalam mengatasi kesulitan membaca Alquran yaitu, memberikan motivasi dan pemahaman kepada peserta didik agar tetap semangat dalam pembelajaran, guru menggunakan metode kelompok yaitu guru membacakan ayat, peserta didik mengikutinya. Dan juga guru mengelompokkan siswa yang pandai sebagai ketua kelompok lalu ketua kelompok mengajari anggotanya secara bergilir. Guru bekerja sama dengan orangtua untuk selalu mengingatkan peserta didik membaca Alquran di rumah.

Pada pelaksanaan pembelajaran terdapat 2 strategi yang digunakan oleh guru yaitu sebagai berikut :

a. Strategi pembelajaran tidak langsung.

Strategi tidak langsung adalah strategi yang lebih menekankan kepada peserta didik pada proses pembelajaran, dimana peserta didik lebih berperan aktif dan guru lebih memperhatikan jika ada peserta didik yang belum pandai membaca Alquran serta menyuruh peserta didik untuk mempelajari apa yang telah diperbaiki oleh guru agar dipelajari dirumah.

b. Strategi pembelajaran ekspositori. 
Annisya Mulia dan Ahmad Kosasih: Strategi Guru PAI dalam Menghadapi Kesulitan Membaca...

Strategi ini pada saat pembelajaran guru lebih berperan aktif dimana guru menjelaskan pembelajaran dan peserta didik hanya memperhatikan guru menerangkan. Pada saat pembelajaran berlangsung peserta didik ada sebagian yang tidak memperhatikan, sehingga peserta didik ada yang tidak memahami apa yang telah disampaikan guru. Disini guru hanya menyampaikan pembelajaran.

Dari beberapa strategi diatas dapat disimpulkan bahwa strategi yang cocok digunakan dalam pembelajaran adalah strategi tidak langsung karena dengan strategi tersebut peserta lebih memahami apa yang dijelaskan oleh guru dan apa yang telah diperbaiki guru agar peserta didik lebih giat lagi sehingga tujuan pembelajaran tersebut dapat terlaksana dengan baik, sedangkan strategi ekspositori guru hanya menjelaskan pembelajaran, pada proses pembelajaran ada beberapa peserta didik yang tidak memahami apa yang dijelaskan oleh guru ketika guru menanyakan kembali apa yang dijelaskannya.

\section{Kesimpulan}

Berdasarkan temuan dan pembahasan hasil penelitian yang telah dilakukan mengenai kesulitan membaca Alquran di kelas V SD Negeri 04 Kampung Dalam adalah sebab-sebab kesulitan membaca Alquran di kelas V SD Negeri 04 Kampung Dalam adalah terbata-bata dalam membaca Alquran, belum mengetahui tanda baca, belum mengetahui panjang pendek, kurang menguasai kaidah ilmu tajwid, tidak mengenal huruf hijaiyah, dan tidak percaya diri atau takut salah dalam membaca Alquran. Faktor penyebab kesulitan membaca Alquran di kelas V SDN 04 Kampung Dalam terbagi menjadi 2 bagian yakni faktor internal dan faktor eksternal. Faktor internalnya ialah kurangnya motivasi dalam diri peserta didik, dan malas dalam belajar. Faktor eksternalnya ialah lingkungan keluarga yang kurang mendukung, lingkungan teman sepermainan yang kurang memadai dan waktu yang sangat terbatas. Faktor pendukungnya ialah sarana dan prasarana yang memadai seperti buku dan Alquran.

\section{Referensi}

Abu Ahmad, W. S. (2008). Psikologi Belajar. Jakarta.

Al-Hafidz, A. W. (2009). Bimbingan Praktis Menghafal Al-Quran. Jakarta: Bumi Aksara.

Al-Manshur, D. G. (2014). Metodologi Penelitian Kualitatif . Yogyakarta: Ar-Ruzz Media.

Chaer, A. (2013). Al-Qur'an dan Ilmu Tajwid. Jakarta: PT. Rineka Cipta.

Drajat, A. (2017). Ulumul Qur'an. Depok: Kencana.

M.Marki, J. (2021). Keutamaan Membaca Al-Qur'an. Jakarta: Kementerian Agama Republik Indonesia

Moleong, J. Lexy. (2009). Metode Penelitian Kualitatif. Bandung : PT Remaja Rosdakarya.

Muhaimin dkk. (1996). Strategi Belajar Mengajar ; Penerapannya dalam Pembelajaran. Surabaya: CV. Citra Media Karya Anak Bangsa.

Raco, J. (2010). Metode Penelitian Kualitatif, Jenis, Karakteristik dan Keunggulannya. Jakarta: Grasindo.

Subini, N. (2011). Mengatasi Kesulitan Belajar Pada Anak. Jogjakarta. 
Wahyudi, M. (2007). Ilmu Tajwid Plus. Surabaya: Halim Jaya.

Zakiah Daradjat, d. (2006). Ilmu Pendidikan Islam. Jakarta: Bumi Aksara. 